\title{
DANSKE FOLKEBIBLIOTEKER I SØNDERJYLLAND I TIDEN MELLEM KRIGENE \\ AF
}

JAKOB PETERSEN

BIBLIOTEKAR VED DET SØNDERJYDSKE LANDSBIBLIOTEK, AABENRAA

*

$\mathrm{D}$

ansk Folkebiblioteksarbejde i Sønderjylland kan føres langt tilbage i Tiden, men det er spredt og lidet sammenhængende. Først i i838 kommer der Perspektiv i Arbejdet, selvom det blev indledet med den Tale, som Orla Lehmann holdt $\mathrm{i}$,Selskabet for Trykkefrihedens rette Brug" den 4. Nov. 1836. Paa Mødet vedtoges det enstemmigt at udvide Selskabets Virksomhed til Sønderjylland, og at Virksomheden skulde bestaa i Udbredelsen af gode danske Bøger. Den gode danske Bog skulde danne Modvægten mod den tyske Kulturs Udbredelse og Indflydelse. Der blev i Aaret efter sendt en Mængde Bøger til Sønderjylland, og de blev alle uddelte som Gaver. Det er denne planløse Fordeling, som harmer "Dannevirke's" iltre og iderige Redaktør, P. C. Koch, saa at Tanken om Folkebibliotekerne blev fostret og sat i Værk. Dette Folkebiblioteksarbejde blev senere udformet og støttet af „Foreningen til Dansk Læsnings Fremme i Slesvig“ og kom til at bære rige Frugter i de Io Aar forud for Treaarskrigen. De førende Mænd i Arbejdet var: Redaktør P. C. Koch, Haderslev; Redaktør Fr. Fischer, Aabenraa; cand. theol. Nis Hanssen Bondesøn fra $\varnothing$. Højst og Professor Chr. Flor. Der blev ialt oprettet 62 danske Folkebiblioteker med ialt 20-25,000 Bind. Af disse laa de 32 nordfor Linien Genner BugtBallum, 28 syd for denne Linie og kun 2 syd for den nuværende Grænse, nemlig i Flensborg og Medelby. De Biblioteker, der havde været i Bønstrup, Grumtofte Sogn og i Nr. Haksted, kunde ikke opretholdes og var derfor gaaede ind. En kortfattet, men langtfra fyldestgørende Redegørelse om Bibliotekernes Virksomhed i Tiden forud for Treaarskrigen findes hos P. Lauridsen: „Da Sønderjylland vaagnede“, 3. Bd. S. 7-20.

Det Resultat, der i det korte Aaremaal før Treaarskrigen blev naaet, var unægtelig glimrende. Det vil bedst kunne forstaaes, naar der gøres opmærksom 
paa, at en Mand som Fr. Fischer i 1838 kunde skrive, at en dansk Bog var en Sjældenhed i Aabenraa, og P. Chr. Koch samme Aar maa sige, at den danske Litteratur var af Mangel paa Tid og Penge stedse fremmed for ham. Endnu i I840 kan Koch klagende skrive til Professor Flor: „... I saa Henseende er Haderslev et magert Punkt for en ustuderet og for alle Bøger blottet Redaktør. Jeg lever paa en Hede, en tør Ørken, og skal dog skaffe Vand til alle Sider." Der laa paa det Tidspunkt en tysk aandelig Fernis over Sønderjylland, og det er intet Under, at der fra tysk Side kunde skrives og tales om, at alle Dannede i Landet kun læste Tysk og intet paa Dansk. Der kan fremføres Eksempler paa, at danske Bøger, der havde et stort Salg nordfor Kongeaa, slet ikke blev solgte i Sønderjylland, selv om de blev udbudte til Salg. Alt dette falder godt sammen med baade P. C. Koch's og Fr. Fischer's Udsagn, og det var i dette Forhold, at Folkebibliotekerne bragte en Ændring.

Syd for den nuværende Grænse lykkedes det at faa oprettet 2 Biblioteker i Flensborg og Medelby, dette er forstaaeligt, naar der tænkes paa Forholdene, som de var i Aabenraa og Haderslev. Det har været vanskeligt for den danske Bog at trænge frem, jo længere den skulde Syd paa. Vanskelighederne i Angel og Mellemslesvig var mangeartede, og her skal kun nævnes, at ingen lærte at læse Dansk, da Skolens Sprog var tysk; alle kirkelige Handlinger blev udførte i det tyske Sprog, og saa godt som alle Embedsmænd var tysksindede eller hvad værre var: Slesvigholstenere. Tiltrods for dette var Folkesproget dansk i en Række Sogne i Angel og Mellemslesvig, selv om det plattyske Sprog her og der var trængt frem. Her laa en stor Arbejdsmark for et dansk Kulturarbejde, som Redaktør P. G. Koch i Haderslev ofte tænkte paa, men aldrig formaaede at faa fat i. Efter Sejren ved Idsted, der gav den vaagnende Nationalfølelse et stærkt Stød fremad, blev det nødvendigt at overveje, hvad der skulde gøres. I Februar og Marts I85 I blev det store Skridt taget, idet de saakaldte Sprogreskripter blev udstedte, der indførte overvejende dansk Kirke- og Skolesprog i de Sogne i Angel og Mellemslesvig, hvor det danske Folkesprog endnu levede. Disse Sprogreskripter har af Eftertiden faaet haarde Domme, men i Realiteten var de et storstilet Forsøg paa at styrke det danske Folkesprog og om muligt fuldstændig fæstne dansk Kulturliv paa de Strøg, hvorom der i Sandhed kunde siges: „at Frø af Ugræs er føget over Hegnet“. Der blev i denne Kulturkamp, der kom til at staa i disse Distrikter, ikke sparet paa Arbejdskraft, ikke heller paa Anordninger; men ved Siden af dette officielle Arbejde løb et uofficielt eller rettere frivilligt Arbejde, der kunde faa en overordentlig stor Betydning, og det var Arbejdet, som blev udført gennem Folkebibliotekerne. Dette Arbejde 
er bleven lidet agtet, ja endog overset, og dog var det efter disse Tiders Forhold et storstilet Arbejde, der ogsaa af Eftertiden maa kræve den dybeste Respekt. Det er om dette Arbejde, der her skal skrives.

Da Krigen brød ud i 1848 , standsede den alt det folkelige Oplysningsarbejde, der var i Gang, og dermed ogsaa Folkebiblioteksarbejdet. Under Treaarskrigen splittedes Bibliotekerne eller de opløstes. Næppe var Freden en Kendsgerning og ordnede Forhold tilvejebragte, inden Biblioteksarbejdet blev genoptaget. Den 27. April r 851 udsendte en Komitee i Aabenraa følgende Opraab:

Opfordrede af en almindelig anerkendt Trang og mangfoldige lydeligen udtalte Ønsker ere Underskrevne traadt sammen i en Komitee, hvis Hensigt og Formaal er, at tilvejebringe dansk Lectüre for den Del af det slesvigske Folk, vi nærmest staar i Berørelse med. De til sin Tid af „Selskabet for dansk Læsnings Udbredelse“ stiftede Folkebiblioteker have givet fuldstændige Bevis for Vigtigheden af danske Bogsamlinger, der er tilpassede efter Folkets Smag og Tarv og tilgængelige for alle. Bøgerne blev søgte og læste med den største Interesse, og skulde der være nogen Tvivl om disse Læseindretningers Gavnlighed, saa kan den hadefulde Iver, hvormed de ansete Tysksindede (f. Eks.; for at nævne Een, Provst Rehhoff) modarbejdede dem, sikkerligen anføres som et Bevis for denne. - Efterhaanden bleve Bøgerne opslidte, og Bibliotekerne kom i Forfald i det de, grundlagde paa en altfor liberal Basis, ikke kunde forsyne sig med nye Tilførsler, og det omtalte Selskabs Kræfter ej heller tillod at vedligeholde dem med stadige Sendelser af friske Bøger. Ikke des mindre bleve de jævnligen afbenyttede, indtil de under Krigen for største Delen bleve adsplittede.

Menigmanden savner nu haardeligen disse ægte folkelige Foranstaltninger og ønsker overalt at nye maatte opstaa. For at virke for dette almindelige Ønskes Opfyldelse, og indseende den store Nytte, Læsningen af gode danske Bøger medfører, have vi Underskrevne derfor forenet os til en

\section{Comitee for dansk Lesnings Fremme}

for saaledes at danne et Foreningspunkt for de enkelte Bestræbelser i denne Retning.

Uden endnu at kunne fremlægge en fuldstændig Plan, der først kan udarbejdes, naar vi kender de Midler, der ville blive stillede til vor Raadighed, bemærke vi blot, at vi ville se at faa oprettet et dansk Folkebibliotek til Underholdning for Byens og Omegnens Beboere. - Ved frivillige Bidrag af Penge og Bøger, samt ved velvillig Forudbetaling af et meget moderat Kontingent for et Aars Læsning, haaber vi at blive sat i Stand til at etablere en Bogsamling, der vil svare til det tilsigtede Øjemed.

Vi opfordre derfor vore patriotiske Medborgere til at række Haanden til denne Plans Iværksættelse, hvis Vigtighed i Nationalitetens Tjeneste er udenfor al Tvivl. Vi haaber ogsaa at fædrelandssindede Mænd i Kongeriget velvilligen ville yde vort Foretagende den Assistance, det saa højligen fortjener. Naar dets Virkelighedsgørelse er sikkret, vil en fuldstændig Plan blive offentliggjort; støttede paa tidligere Erfaringer tro vi dog foreløbigen at kunne vedtage, at Læsningen $i$ et helt Aar kan tilstedes for $3^{\circ}$ Sk. Cour., i et Halvaar 
for 20 Sk. Cour., og enkelte Bøger erholdes for I Sk. Cour. Stykket. Uformuende tilstedes Læsningen gratis.

Velvillige Bidrag modtages af enhver af de Underskrevne.

Aabenraa, 27. April 1851 .

$\begin{array}{ccc}\text { Fr. Fischer. } & \text { M. Bahnsen. } & \text { P. H. Petersen. } \\ \text { Redacteur } & \text { Raadmand } & \text { Sognefoged for Ensted Sogn. Dbmd. } \\ \text { C. H. Moller. } & \text { A. Esschildsen. } \\ \text { Gaardejer paa Skovgaard. } & \text { Sognefoged for Jordkjær Sogn. Dbmd. } \\ \text { Jergen Nissen. } & \text { Joh. E. Eschelsen. } \\ \text { Sognefoged for Riis Sogn. } & \text { Moller paa Ronde Molle i Loit. }\end{array}$

Den 30. Juli $185 \mathrm{I}$ udsendtes en lignende Opfordring fra Tønder underskreven af Sekretær H. C. Refslund, Rektor N. V. Müller og Branddirektør A. Bauditz. At det netop blev Aabenraa og Tønder, der udsendte disse „Opfordringer“, er ikke nogen Tilfældighed. Det havde i disse to Amter været overordentlig vanskeligt at fremme Sagen før Krigen, og da ganske særlig i Amternes sydlige Sogne. I selve Tønder By fandtes der før Treaarskrigen intet dansk Bibliotek. Som det fremgaar af Opraabet fra Aabenraa, havde Folkebibliotekerne været udsatte for Angreb, og det især fra Provstens Side, det samme er Tilfældet med Provsten i Tønder. I deres Følge er saa Præsterne og med dem igen de allerfleste Lærere gaaede. Det har været Folket selv, der bar Bibliotekssagen frem, og det er da ogsaa til Folket, at „Opraabene“ udsendes. Klogeligt havde Mændene fra Aabenraa ikke udeladt Muligheden af Hjælp fra Kongeriget, men netop bejlet til en saadan Hjælp. Det blev ogsaa nordfra, at Hjælpen kom, ja det er et stort Spørgsmaal, om det var bleven til noget synderligt, hvis de to og lignende andre Komiteer skulde have klaret sig selv. Vanskelighederne vilde sikkert være vokset dem over Hovedet, saa det var og blev en Nødvendighed, at der maatte gøres noget fra anden Side. Betydningen af Opraabet fra Aabenraa er da ogsaa denne, at det straks faar Ørenlyd, og at der kunde henvises til, at det sønderjydske Folk var interesseret i, at et Biblioteksarbejde blev gjort. Den I 7. Maj I85I, altsaa forud for Tønder Opraabet, blev der gennem „Fædrelandet“ udsendt et Opraab med følgende Ordlyd:

„I Bladet „Freia“ for Løverdagen den 3die d. M. findes en Artikel dateret Aabenraa den 27 de f. M., hvori Redacteur Fr. Fischer, Raadmand M. Bahnsen, Gaardejer H. C. Møller, Sognefogederne H. P. Petersen, A. Eskildsen og Jørgen Nissen, samt Møller Joh. E. Eschelsen, efter at være sammentraadt i en Comitee for dansk Læsnings Fremme iblandt en Del af den slesvigske Befolkning, hvormed de nærmest staa i Berøring, opfordre deres Medborgere i Slesvig til at række Haanden til bemeldte Øjemeds Opnaaelse og 
tillige yttre den Forventning at fædrelandssindede Mænd i Kongeriget ligeledes ville yde dem den i saa Henseende fornødne Understøttelse.

At søge saa vidt muligt at afhjælpe den Trang til god dansk Læsning, som, ifølge ovennævnte Slesvigeres Erklæring og mangfoldige andre paalidelige Vidnesbyrd, nu efter at en lovlig Tilstand er bleven gjenoprettet i Hertugdømmet, paany og med forøget Styrke har begyndt at gjøre sig gjældende i Nord- og Mellemslesvig, maa saa meget mere anses for at være af Vigtighed, som en sand og levende Nationalitetsfølelse tildels er betinget af den Erkendelse, at Modersmaalet fortjener samme Agtelse, som andre Sprog, og at det har en Litteratur, hvorved Folket har Grund til at glæde sig. Da imidlertid „Selskabet for Trykkefrihedens rette Brug “, der i sin Tid med Nidkærhed søgte at fremme den slesvigske Almues Oplysning, forlængst er opløst, og „Foreningen til dansk Læesnings Fremme i Slesvig" som i Aarene I839 til I847 ligeledes ufortrødent arbejdede til et lignende Maal ogsaa har ophørt at virke, have vi, efter den i ovennævnte Artikel og adskillige andre Meddelelser dertil givne Anledning, samt i Haab om kraftig Bistand, besluttet indtil videre at fortsætte den af bemeldte Forening tidligere udviste Virksomhed for Oprettelsen af danske Folkebiblioteker i de Distrikter af Slesvig i hvilke der findes dansk Folkesprog.

I det vi derfor tillader os at rette den indstændige Bøn til vore Medborgere og Medborgerinder at understøtte et Foretagende, der griber dybt ind i de vigtigste nationale Interesser, nære vi tillige den tillidsfulde Forventning, at det danske Folk, der i tre lange Krigsaar med saa stor Udholdenhed har bragt Fædrelandet saa mange Ofre ikke heller vil staa tilbage ved denne Lejlighed.

Saa kjært det naturligvis vil være os at modtage Gaver af gode danske Bøger, som egne sig til Læsning for Menigmand, naar saadanne tilstilles os portofrit, turde vi dog især gjøre Regning paa Pengebidrag, da det uden disse ikke vil være os muligt at faa Sagen ordnet paa tilfredsstillende Maade. ... “

Kjøbenhavn, I4. Maj I85I.
G. Borries.
A. L. C. de Conninck.
Cancelliraad.
C. Levinsen.
P. C. Mangor.
Cancelliraad.

Det var nye Mænd, der traadte til, saa at sige overalt. Det eneste af alle de Navne, der findes under de 3 Opraab, der er kendt fra før I 848 er: Fr. Fischer. Der kunde med god Grund spørges om, hvor de andre var bleven af. Der er ingen Tvivl om, at Politiken tog en god Del af dem, andre følte sig maaske tilsidesatte o. s. v. Det kan ogsaa tænkes - det kendes endnu i vore Dage - at man har lagt sig til Ro med Tanken om, at nu er vi Danske, og skulde der gøres noget for det danske ud over det, der bliver gjort, nuvel saa bliver det Præsternes og Lærernes Opgave. Er Mændene ny i Sønderjylland, saa er de det ogsaa i København, det var ganske andre Mænd, der tog sig af Sagen før Treaarskrigen. De fire Mænd i København, der dannede „Den midlertidige Comitee for Oprettelsen af danske Folkebiblioteker i Slesvig “, er lidet kendte i Modsætning til de Mænd, der udførte et lignende Arbejde forud for Treaarskrigen. Det blev deres 
Lod, som saa mange andres i den Tid, der her er Tale om, at da Gerningen var gjort, glemtes den Indsats, som de udøvede. Om selve det Arbejde, der blev udført af Komiteen, er der udsendt 4 Beretninger, af hvilke den ene er aftrykt i „Slesvigske Provindsialefterretninger“ 2. Bd. S. 393-4I I. Det vigtigste Materiale til Belysning af Folkebibliotekernes Historie i Sønderjylland i det nævnte Tidsrum er de to Protokoller, som Komiteen har ført over alle udgaaede Skrivelser, Boglister m. m., og som findes opbevarede paa Rigsarkivet. Det er paa Grundlag af dette Materiale, at denne Afhandling er skreven. Inden jeg gaar over til Behandling af Emnet, vil det være fornødent ganske kort at give et Omrids af de 4 Mænds Liv, der bar Sagen frem, saa den fik en virkelig Betydning.

Gustav Borries er født den I. Juli I8 2 i København. Han var cand. polyt. Studerede i nogle Aar Fabriksvirksomhed i Tyskland, særlig Kattuntrykkeri og Stearinlysfabrikation. Han blev efter sin Hjemkomst Inspektør ved den polytekniske Læreanstalt og Meddirektør ved „Fredens Mølle“. Han døde i en ung Alder kun 48 Aar gammel, den 2. April r86o. Ved sin Død testamenterede han Komiteen 500 Rbd., der skulde udbetales med 5o Rbd. aarlig i ro Aar. Hans Eftermæle giver ham det smukke Lov, at han var en for vor nationale Udvikling og Selvstændighed varmt følende Mand. Lige til sin Død vedblev han at skænke Rødding Højskole sin virksomme Deltagelse. Han var et utrætteligt Medlem af den midlertidige Komitee for Oprettelsen af danske Folkebiblioteker i Slesvig; Dannelsen af denne Komitee skyldes væsentlig ham. Han indtager en værdig Plads i Rækken af Danmarks bedste Sønner.

Adolph Louis Charles de Conninck er født den 3. Juni 1814 i København. Han var i I 85 I ansat som Bureauchef ved Rigsdagen og blev samme Aar udnævnt til Kancelliraad. Var Medudgiver af Juridisk Tidsskrift og blev efter kort Tid Eneredaktør af Tidsskriftet. Blev senere Justitssekretær ved Landsoverretten og døde den 27. Januar 1872. Han var i sin Ungdom en varm Ven af Frihedsbestræbelserne og en flittig Medarbejder ved Oppositionsbladene. Senere ønskede han Valgretten indskrænket. Han var en meget godmodig Mand, der efterlod sig mange Venner. Digteren H. P. Holst har skrevet et lille Mindedigt om Vennen.

Carsten Levinsen er født den 25. April 1812 i Holbæk ved Randers. Var først Bogtrykkerlærling og senere Svend ved et Trykkeri i Randers. Blev derefter Student og tog i i 842 teologisk Embedseksamen. Han vandt i i 847 den af „Selskabet for Trykkefrihedens rette Brug“ i i841 udsatte Præmie ved „en populær Fremstilling af den christelige Kirkes Historie“. Blev Præst i 1849, først ved 
Fredriks Hospital, senere residerende Kappellan ved Trinitatis Kirke. Han har udgivet en Række Skrifter. Vigtigst er hans „Real-Concordants“, der udkom I854, og „Verbal-Concordants“, der udkom I858. Han var Svoger til Pastor Mørk-Hansen i Felsted og opholdt sig hos ham i Ferietiden. Han døde den 9. August 1873. I en Nekrolog i „Fædrelandet“ fremhæves han som en Mand af ædel Tænkemaade, fast Karakter og en stærkt udviklet Pligtfølelse.

Peter Carl Vilhelm Eduard Mangor er født den i 7. Nov. I 799 i København. Tog i 1822 juridisk Eksamen, gik Embedsvejen og var i 1845 bleven Justitssekretær ved Kriminal- og Politiretten. Blev Kancelliraad i 1846 og Justitsraad i 1856. Han døde den 7. November I883. Mangor var Komiteens „faste Haand“. Det er ham, der udførte det store Arbejde. Hans Breve og Boglister viser ham som en omhyggelig og samvittighedsfuld Embedsmand.

I Løbet af kort Tid modtog Komiteen betydelige Boggaver og Pengebidrag. Gennem Aarene blev den ved med at modtage Gaver, og det har været af stor Betydning. En egentlig Forening blev aldrig stiftet, saa Komiteen ofte har været henvist til det Tilfældige, hvad ikke var af det gode. Af overordentlig stor Betydning har det været, at Komiteen blev indsat som Arving til den Gaard, som Professor J. F. Schouw havde modtaget af Jyderne for at gøre ham valgbar til de nørrejydske Stænder. Professor Schouw døde den 28. April r852. Gaarden blev solgt for 4687 Rbd., og denne Sum sammen med Renterne blev stillet til Komiteens Raadighed. Dette gav den et fast Holdepunkt i Tilværelsen. Arven blev forvaltet af Boets Eksekutorer, der bestod af Professor H. N. Clausen, Professor N. L. Høyen og Konferentsraad P. D. Bruun. Af de Ansøgninger, der Aar efter Aar er sendte til de tre Herrer, kan det ses, at de allerfleste Penge af dette Bo er gaaede til Arbejdet i Angel og Mellemslesvig. Betydelige Pengebidrag modtog Komiteen fra: Kongen, Arveprinds Ferdinand, Direktionen for det Classenske Fideikommis, Overskud fra det nordiske Studentermøde i København (550 Rbd.), Det slesvigske Legat, Embedsmændene under det slesvigske Ministerium, Medlemmer af Folketing og Landsting, Embedsmænd i Slesvig, Flensborg og Aabenraa, fra Byerne: Holbæk, Helsingør, Næstved, Slagelse, Kalundborg, Køge, Viborg, Horsens, Skive og Stubbekøbing, samt Sognene: Boeslunde og Errindlev, Legatet efter afdøde Inspektør Borries; fra danske Købmænd, der var bosatte i Hamborg, London, Hull, Liverpool, Glasgow og Leith (tilsammen en Sum paa $555 \mathrm{Rbd}$.) $\mathrm{m}$. fl. Det vilde føre alt for vidt at opregne enkelte Personer, nævnes skal kun at Bidragene varierede fra $100 \mathrm{Rbd}$. til I Mk. En betydelig Indtægt har de Penge været, der sendtes Komiteen fra $\mathrm{Bi}-$ bliotekerne i Sønderjylland. Komiteen modtog $i$ Tiden fra $185 \mathrm{I}-64$ alt $i$ alt 
I5,3 I4 Rbd. Bøgerne kom ligeledes fra meget forskellig Side, nævnes skal her: Indenrigsministeriet, Det slesvigske Ministerium, Den slesvigske Forening, Det kgl. Landhusholdningsselskab, Foreningen til opbyggelige Skrifters Udgivelse blandt Folket, Samfundet til den danske Litteraturs Fremme, Selskabet til Udbredelse af Danmarks Oldskrifter, Det kgl. Teater, Selskabet for Udgivelsen af danske Folkeskrifter i Haderslev, Bladredaktioner, Bogforlæggere og mange enkelte Personer, blandt disse sidste skal kun nævnes: Regenburg og H. A. Kryger. I Tidsrummet I $_{5} \mathrm{I}-64$ blev der ved Hjælp af Gaverne og ved Køb $i$ alt samlet og udsendt til Bibliotekerne i Sønderjylland 66,457 Bøger og Smaaskrifter.

Komiteen i København havde, som det fremgaar af Opraabet, raadført sig med Folk, der havde Indsigt i Forholdene i Sønderjylland. Det nævnes intet Sted, med hvem det er Komiteen har raadført sig, det bør dog antages, at det har været med Professor Flor og Dr. med. Manicus i Flensborg. Manicus er i alle Tilfælde den Mand, der i de første Aar er Mellemled mellem Komiteen og Præsterne i Angel og Mellemslesvig. Der var heller næppe nogen enkelt Mand, der kendte Forholdene i de Egne saa godt som han. Der er en Del, der kan tyde paa, at Komiteen ogsaa har haft Forbindelse med Regenburg, men det kan ikke bevises ud over det, at der af et Brev erfares, at et Medlem af Komiteen har haft en personlig Samtale med ham, og at Regenburg har lovet Komiteen en Del Bøger. Opraabet fra Aabenraa har været en meget kærkommen Opmuntring, det har tilsyneladende været det store Plus, der satte Virksomheden i Gang i København. Om de to Komiteer har haft nogen Forbindelse med hinanden forud for Opraabenes Udstedelse vides intet. Der er intet der taler for det. Opraabet i Aabenraa er skrevet af Fr. Fischer, det er der ingen Tvivl om, da det har en afgjort lokal Karakter. Komiteen følte sig som Arvtager efter „Foreningen til dansk Læsnings Fremme i Slesvig“, hvad ligeledes tydeligt fremgaar af Opraabet; der er dog intet der viser en Forbindelse mellem de to Bestyrelser, ud over det, at Inspektør Borries og Pastor Levinsen har været stærkt med i hele det sønderjydske Røre forud for Treaarskrigen. Stor Betydning har det haft at Aabenraaopraabet smittede, og at der sammentraadte lignende Komiteer andre Steder, det skete foruden i Tønder ogsaa i Løgumkloster og Graasten. Disse Komiteer dannede tilligemed, $\mathrm{i}$ alle Tilfælde i forste Omgang, Bestyrelse for Biblioteket paa Stedet og tog Haand i Hanke med Omegnens Sognebiblioteker. Bestyrelserne eller Komitemedlemmerne i Aabenraa og Tønder er nævnte, her skal endnu kun nævnes, at til Aabenraa sluttede sig Sognene: Ensted, Hjordkær, Rise og Løjt, til Tønder Sognene: Tinglev, Ravsted, Højst, Hostrup, Abild og Emmerlev. Løgumkloster omfattede Sognene: Nr. Løgum, 
Brede og Landsognet, altsaa det gamle Løgumkloster Amt, Bestyrelsen bestod af: Købmand Christensen, Præsterne Garde og Krarup og Amtsforvalter Weilbach. Biblioteket $\mathrm{i}$ Graasten havde ingen Forbindelse med Omegnen udover Adsbøl Sogn, Bestyrelsen for Biblioteket var: Pastor Engel, Dr. med. Boye, Apoteker Henningsen og Farver Jørgensen. Forbindelsen mellem Byerne og Sognene i Oplandet løstes ret hurtigt, idet der blev oprettet selvstændige Sognebiblioteker i alle de nævnte Sogne. Reglen var denne, at Ledelsen laa i Præsternes eller Lærernes Hænder. For de I03 Biblioteker, hvor Lederen er nævnt, stiller Forholdet sig saaledes, at 68 var Præster, 22 var Lærere, 8 var Embedsmænd og kun 5 var Sognefogder eller Gaardmænd.

Af Breve, Indberetninger m. m. ses det tydeligt, at Sjælen i hele Arbejdet $i$ Sønderjylland var Præsterne, i Angel og Mellemslesvig var det dem alene, der havde med Arbejdet at gøre, paa en enkelt Undtagelse nær. Der er saaledes god Grund til at standse ved de Præster, der kom ned til Egnene syd for den nuværende Grænse. Det er en ejendommelig Skare af unge Mænd, af hvilke den ældste var 42 Aar, Pastor Lassen i Adelby, og den yngste H. F. Fejlberg, der var 24 Aar, da han kom ned til St. Solt som Kapellan. Af de 30 Præster, der kom ned til disse Egne, var de 23 under 35 Aar. Det var imidlertid Mænd, der senere hen har vist, at de var dygtige og veluddannede til Gerningen. Mænd, som Pastor Hagerup i St. Solt, H. F. Rørdam i Satrup og H. F. Fejlberg først i Valsbøl, senere i St. Vi, har indskrevet deres Navne i dansk Videnskab. Stærkest blandt dem alle stod vel nok Pastor Graae i Flensborg, der var utrættelig i alt, hvad der kunde fremme den danske Sag. Alle har de tillagt Bibliotekerne en stor Betydning, og alle uden Undtagelse har været glade ved dem, da de var dem en kærkommen Hjælp i deres Arbejde. De har alle følt Vanskelighederne, uden at de til at begynde med har været klar over, hvordan de skulde overvindes. De var kommen til Egne, hvor det danske Sprog blev talt i større eller mindre Udstrækning, eller dog i det mindste blev forstaaet selvom det ikke taltes. Befolkningen ansaa ikke sit danske Samtalesprog for et Sprog, der skulde plejes, tværtimod det var dem generende, saa snart de kom udenfor Sognets Grænser. Befolkningen talte helst tysk, et saakaldt tysk, med Præsten og andre Standspersoner, og det har krævet megen Takt og Klogskab fra Præstens Side at faa den Vane brudt. Det danske Sprog var i disse Egne intet Kultursprog, og den første og største Opgave maatte være at hæve Sproget ud af dets ynkværdige Stilling. Her gaves kun én eneste Vej, og den var at lade det danske Sprogs Kilder, den danske Litteratur, som en frugtbargørende Strøm risle ned over Sindene, saa langt der endnu var Mulighed for det. Dansk Læsning var Midlet, men hvorfra 
hente det? I Flensborg fandtes intet dansk Blad, intet dansk Tidsskrift, ingen ordentlig Bogsamling, kort sagt intet udover det dansksindede, men paa tysk skrevne „Flensburger Zeitung“. Danske Bøger var en ukendt Ting, og selv Læsning er paa den Tid bleven betragtet som en daarlig Vane. Her var en gold Ørken, der trængte til levende Vandstrømme. Her blev Bibliotekernes Betydning enorm, intet Under at Præsterne greb disse med Begærlighed, da de blev dem tilbudte.

Den 20. Oktober 1851 kunde Komiteen afsende de første Bøger, de gik til Aabenraa og Flensborg; 4 Dage senere afgik en Sending til Tønder, og den 3 I. Oktober en til Haderslev. Det lykkedes, inden Aaret var tilende, at faa afsendt I 1,789 Bind til 50 Biblioteker, af disse laa I 8 sydfor den nuværende Grænse, og de 18 Biblioteker havde modtaget 4,45I Bind. Ved Udgangen af I855 er der oprettet 90 Biblioteker, af hvilke de 4 I ligger syd for Grænsen, og da Krigen brød ud i 1864 var der i alt oprettet 143 Biblioteker, og af disse 56 syd for den nuværende Grænse. Hvis alle disse Biblioteker var indtegnede paa et Sønderjyllandskort, saa vilde det vise sig, at de fleste laa tæt om den nuværende Grænse, saavel nord for som syd for. Hovedvægten for hele Arbejdet var lagt i og omkring Flensborg. Her stod Kampen, og her skulde Indsatsen gøres. Der var planlagt Oprettelsen af et stort Centralbibliotek i Flensborg, med A. D. Jørgensen som Bibliotekar, denne Plan maatte skrinlægges, da Krigen og dens Følger hindrede dens Udførelse. Det er lettere at gøre Rede for, hvor der ingen Biblioteker fandtes, end de Steder hvor de var. I de saakaldte blandede Distrikter, der alle laa syd for den nuværende Grænse, undtagen Bov og Udbjerg og Sogne, der hørte med til dem, var der Biblioteker i alle Sogne undtagen: Enge. Nordfor Grænsen var der Biblioteker i alle Sogne indenfor det nuværende Grænseomraade undtagen i: Ringenis og Uge. Desuden savnedes der Biblioteker i følgende Sogne i Haderslev Amt: Aastrup, Bjerning, Moltrup, Maugstrup, Jægerup, Skrydstrup, Vedsted, Øsby, Oksenvad, Jels, Lintrup, Hygum og Fole. I Tønder Amt: Hvidding, Roager, Rejsby, Vodder, Romø, Ballum, Visby og Møgeltønder. I Sønderborg Amt: Havnbjerg, Svenstrup, Egen, Ketting og Asserballe. Alt i alt 28 Sogne nordfor Grænsen, naar de 2 Sogne i Aabenraa Amt: Ringenis og Uge tælles med. Komiteen var godt klar over dette Forhold, og skriver i et Brev: „. . . hvorimod vor Opmærksomhed senere ogsaa er bleven henvendt paa følgende Steder, der alle have dansk Kirke- og Skolesprog, men af hvilke nogle have tyskuddannede Præster, nemlig: Kegenæs, Ringenis, Uge, Kværs, Arrild, Vedsted og Maugstrup“. Det lykkedes at faa Biblioteker i nogle af de nævnte Sogne, men som det fremgaar af ovennævnte ikke $i$ alle. Der kunde heldigvis ogsaa ske 
noget andet, der var mere opmuntrende. Fra Munkbrarup Sogn meddeles der, at Præsten, der var tysksindet, ikke vilde have noget med de Sager at gøre, ja endog paastod, at ingen gad læse Dansk; her oprettedes et Bibliotek ved Hjælp af Degnen, der hed Wotje. Han gjorde det saa godt, at der var Udlaan ved alle Sognets Skoler. Han modtog Biblioteket i Februar 1852. Pastor Mule i Fjolde har i sine „Minder fra den yderste Sproggrænse“ meddelt, at: „Betegnende er det saaledes, at der i Aaret 1853 i Sterup Sogn, som grænser op til Nr. Brarup og Satrup Sogne, dannede sig en dansk Læseforening, hvis Medlemmer sammenskøde Bidrag til aarlig Anskaffelse af gode danske Bøger. En saadan Forening stiftedes ligeledes af Beboerne i Gumtofte Sogn, hvor forøvrigt Angelboens danske Natur vel kom til kraftigst Gennembrud ogsaa i kirkelig Henseende. "Sterup fik et Bibliotek i $185^{1}$ og Grumtofte fik det i Januar 1852. Det, der er sket her, er det samme, som skete ved en Række Biblioteker i de rent danske Egne af Sønderjylland, at der blev indsamlet Penge, der blev sendt til Komiteen i København, og for hvilke saa denne igen sendte Bøger, der var særlig ønskelige. Blandt de 143 Biblioteker laa en Del udenfor det vi nu kalder Sønderjylland, i de 8 Sogne, paa Ærø og i Egnen omkring Ribe ialt 4. Ligeledes laa en Del udenfor de blandede Distrikter, i de tyske Distrikter, disse var: Kampen og List paa Sild, Vyk, Vriksum og Niblum paa Før, Amrum og Nibøl. En Del af det Omraade, hvor disse 7 Biblioteker laa, hører med til Enklaverne. Her var mange danske Sympatier og et enkelt Sted, som List paa Sild, var dansktalende. 2 Biblioteker i Slesvig og Rendsborg var nærmest Garnisonsbiblioteker.

Bogbestanden var $\mathrm{i}$ alle Biblioteker ret ensartet, men der var ogsaa ret afgørende Forskelle. Det ensartede Præg fik de derved, at hele vor Guldalderlitteratur var repræsenteret, selv om det ikke var ved de samme Bøger. Ved at gennemgaa de mange skriftlige Fortegnelser, som findes i de ovennævnte Protokoller, viser det sig, at Ingemanns Romaner, Blichers Noveller og Holbergs Komedier har været Grundstammen i alle Biblioteker. Af særlige folkelige Forfattere, der har været yndede og stærkt efterspurgte, staar T. Rumohr (P. P.) og Carit Etlar, dernæst i Flæng: H. C. Andersen, Hostrup, J. L. Heiberg, Carsten Hauch og M. A. Goldschmidt, ogsaa de fandtes i alle Biblioteker. Endvidere Oversættelser af Walter Scott, Charles Dickens, Marryat og J. F. Cooper. Let Læsning er bleven budt gennem Dansk Folkekalender, Morskabslæsning for den danske Almue, Elmquist's Læsefrugter m. m. Af egentlig oplysende Litteratur findes der yderst lidet, det vigtigste har været Grundtvigs Oversættelse af Sakso og Snorre, om disse to Bøger hedder det til Gengæld, at de næsten er lige saa yndede som Ingemanns Romaner. Endvidere de Skrifter, der blev udgivet af „Dansk 
Folkeskriftsselskab i Haderslev“, de Ting, der i sin Tid udkom hos „Selskabet for Trykkefrihedens rette Brug“, Thiele: „Danmarks Folkesagn“ og Barfods „Fortællinger af Fædrelandets Historie“, samt Allens „Det danske Sprogs Historie i Hertugdømmet Slesvig“. Den afgørende Forskel laa i de mange vidt forskellige Bøger som skyldes Boggaverne. Boggaver har alle Dage og til alle Tider været et tveægget Sværd. Det viser sig ogsaa her, det er et fuldstændig Virvar af de mest forskellige Ting. Komiteen har taget alt for varsomt paa Tingene, der er ikke kasseret nok af alt det, der er bleven den tilsendt. Naar der saaledes, for at nævne nogle Eksempler, udsendes enkelte Aargange af „Dansk Folkeblad“, „Riises Archiv“ Goldschmidts „Nord og Syd“, saa er det en ren Misforstaaelse. Af religiøs Litteratur sendtes der en utrolig Mængde, det var sikkert rigtigt, men ogsaa her har Tilfældighederne spillet Komiteen mangt et Puds. Hans Tausens udvalgte Prædikener har saaledes ikke været paa sin Plads i Eskriis Sogn, det er ikke Læsning for Menigmand. Værst af alt har den oversatte Litteratur været, Bøger uden Forfatter kun betegnede med „Oversat efter det Engelske" burde have været overgivet til Ilden, og ikke sendt ud til et folkeligt Pionerarbejde.

Ved en Del af Bibliotekerne var der Børnebogsamlinger, og i Byerne Aabenraa, Flensborg og Tønder var de selvstændige. Børnebøger i Ordets nuværende Forstand har det været usigeligt smaat med. Af dem der blev udsendte kendes nu kun to: Robinson Kruso og Asbjørnsens Eventyr. Marryats og Coopers Romaner var ikke Børnelæsning paa den Tid. Boggaverne har selvfølgelig ogsaa her øvet deres Indflydelse.

De af Komiteen sendte Bøger har selvfølgelig været underkastet en ret stærk Kritik, og det ikke alene af Præsterne, men Menigmand kunde ogsaa tage til Genmæle mod det, der blev sendt. Bøgerne imødekom langtfra de Ønsker, der var fremme. Disse Ønsker var ret beskedne, naar saaledes en Gaardmand, Falle Anker i Skovhus, der ledede Biblioteket i Aller Sogn, ønsker T. Rumohr's Bog: Peder Tordenskjold, og ikke faar den, saa er det en stor Fejl fra Komiteens Side. Paa alle Anker og Kritik svarer Komiteen med stor Ro og Værdighed, i det den gør gældende, at den ikke har faaet den Indflydelse paa Bogvalget, som den kunde have ønsket. Den Plan, den havde lagt, har den maattet afvige fra, da der kom langt flere Bidrag i Bøger end i Penge. Den var godt indforstaaet med, at Bøgerne var af højst forskellig Værd, men det kunde den ikke ændre. Til dette kom, at mange af de ønskede Bøger var udsolgte eller stod i en Pris, som den ikke syntes at kunne give. Dernæst maatte Komiteen altid være rede til at yde Støtte, naar der blev stillet Krav om nye Biblioteker, og have Midler disponible til det. 
Endelig kan den konstatere, at det er vanskeligt at tilfredsstille Folk, da det, der $ø n s k e d e s$ ét Sted, frabeder man sig at faa et andet Sted. Kritikken ebber dog ud, da det maa siges, at Komiteen i det store og hele søgte at raade Bod paa Manglerne, saavidt det stod i dens Magt. Den har ogsaa søgt at imødekomme ethvert rimeligt Ønske, naar den havde Midlerne til det, eller hvis de blev tilstillet den, og den har altid været rede til at hjælpe med Raad og Daad.

Et svagt Punkt var og blev Bibliotekernes Ordning. Den kendes der næsten intet til. Bibliotekerne har været opstillet i Skolerne, og hvor dette ikke var muligt i Præstegaardene. Kun et Sted har der været Ønske fremme om at faa et Biblioteksværelse, og det var i Flensborg. Da der bliver indsendt et Andragende om en egen Skolebygning, staar der i dette Andragende følgende: "- - Hertil kommer endnu, at der maa sørges for Lokale saavel til et Skolebibliotek, som og til et stort Sognebibliotek paa henved Iooo Bind, hvilke begge er skænkede til den danske Menighed af Comiteen for Oprettelsen af danske Folkebiblioteker i Slesvig og af patriotiske Medborgere." Det er alt, hvad der vides om selve Ordningen, den er der tilsyneladende ikke bleven lagt synderlig Vægt paa. Det eneste, der blev lagt Vægt paa, var at der blev optaget en Fortegnelse over Bøgerne, og at den om muligt blev trykt til Brug for Laanerne. Dette Forsøg paa at fremme en lille Smule Orden, er der, saavidt ses kan, ikke taget Hensyn til. Der findes ingen trykte Fortegnelser over Bogsamlingerne i Sønderjylland fra dette Tidsrum.

Om Udlaanet vides ligeledes meget lidt. Der findes ingen Udlaansprotokoller, de er alle gaaet tabt, hvis der da har været nogen. Udlaanet har været gratis; selvom der har været en hel Del Biblioteker, der har forlangt Betaling, saa har denne nok været saa lille, at den har været betydningsløs. Betalingen har sikkert været mere beregnet paa de velstillede, hvad ogsaa er antydet i Opraabet fra Aabenraa. Syd for Grænsen har Udlaanet været gratis helt fra første Færd, men ogsaa her kunde som alt nævnt samles Penge ind til Styrkelse af Biblioteket. De Tal, der findes, maa behandles med stor Varsomhed, da de alle som det vil ses er omtrentlige eller for at sige det mere præcist takserede. Tallene er for det aarlige Udlaan, men der er ikke angivet i hvilket Aar; de hidsættes dog, da de nu en Gang findes: Rylskov 450 Bd., Grumtofte $45^{\circ}$ Bd., St. Solt $75^{\circ}$ Bd., Stenbjerg 760 Bd., Eskriis I 000 Bd., Oversø I 300 Bd., Valsbøl r 300 Bd., Vanderup 2000 Bd. og i Flensborg 3000 Bd. En bedre Maalestok for Udlaanet er Tallene fra Fjolde Sogn, her er bleven taget en Statistik, der viser det rigtige. I Beretningen hedder det: „-- - Bøgerne bliver medtagne af Slid. I Vinteren I852-53 udlaantes der 34 I Bind. Vinteren I859-6o var det steget til 864 Bind. “ At der 
har været en stærk Efterspørgsel, kan ses af, at de stærkest efterspurgte Bøger blev fornyede i I859 og 186o, det gælder fornemlig Ingemanns Romaner.

Ved Siden af Biblioteksarbejde gik ogsaa et Arbejde med Uddeling af Bøger. Dette Arbejde var baseret paa Tillidsmænd. Komiteen havde mindst én Tillidsmand i hver By, men ingen ude i Sognene. Det er kendte Mænds Navne, vi her møder, men de skal nævnes, ikke alene fordi de fortjener det, men ogsaa fordi disse Mænd har været Komiteens Raadgivere i mange Ting. I Aabenraa var det Amtsforvalter Worsaae, efter ham Rektor Buch, tilsidst Apoteker Stisgaard. I Flensborg: Redaktør Dr. med Manicus, Pastor Graae og Overlærer Monrad. I Tønder: Rektor Møller, Seminarielærer C. Appel. I Sønderborg: Borgmester Finsen og i Haderslev: Pastor Helweg. Der blev gennem disse Mænd sendt en hel Del Bøger ud over Landet, særlig: Det nye Testamente, Salmebøger, Luthers Katekismus m. m. I et stort Antal Eksemplarer udsendtes en Bog af F. H. A. Behrmann: „Anvisning til Skov- og Hegnsplantning især for Landmænd i skovløse Egne. “ Bogen var en Gave fra „Det kgl. Landhusholdningsselskab“. Hvormange Skrifter der er udsendt som Gave vides ikke. Komiteen har været uhyre forsigtig med, hvad det var, den udsendte. Forstander Høgsbro i Rødding ønskede saaledes i 1853 at faa Beretningen om Rødding Højskole uddelt gennem Komiteen og har vel i god Tro sendt den et Antal Eksemplarer. Da der imidlertid ingen blev uddelt, har Høgsbro henvendt sig til Komiteen med Spørgsmaal af hvilken Grund og faar Svaret: „- - er sket med velberaad $\mathrm{Hu}$, da Komiteen, baade i de tidligere og i de nuværende Omstændigheder har faaet tilstrækkelig Oplysning til at gaa frem med al mulig Forsigtighed og af den Grund har troet at burde forbigaa en Meddelelse, som man befrygter, mer vil interessere den danske Sags Fjender end dens Venner". De raader Forstander Høgsbro til at sende Beretningerne direkte til Komiteens Tillidsmænd i de 5 Byer, og om muligt faa dem til at udsende Beretningen til Bibliotekerne i deres Omraade. Denne Forsigtighed bibeholdes gennem Tiderne og har sikkert friet Komiteen for mange Vanskeligheder i de politisk bevægede Tider. Der kunde ved denne Sag være noget der tydede paa, at Komiteen var bange for at blive taget til politisk Indtægt, og det har den været klar over, at det kunde den ikke være tjent med, da Midlerne til et fortsat Arbejde gerne skulde tilfyde den fra hele Befolkningen.

I Juli 1863 var Komiteens Midler udtømte, alle Penge fra Legater og lignende var brugte. Den skriver saa et Brev til „Det-Classenske Fideikommis“ for om muligt at faa nye Midler. Brevet er en stilfærdig Beretning om Vanskelighederne, der er i Færd med at taarne sig op om hele Arbejdet: „- - Uagtet vor Virksomhed hidtil har haft et heldigt Udfald, staar dog endnu meget tilbage, inden 
vi kunne ønske at ophøre med den, i det Trangen til dansk Læsning, tiltrods for den tydske Agitation mod Foreningen, saavel som imod alt Dansk, i den Grad er tiltagen for den slesvigske Befolkning især i Mellemslesvig, hvor Agitationen har sit Arnested, at vi stadig modtager Begjæringer, dels om Oprettelsen af nye Folkebiblioteker, dels om en Forsyning med nye Bøger, og det ikke alene fra blot danske, men ogsaa fra blandede, ja selv tyske Distrikter, hvor en Del af Menigheden taler Dansk ...“. Dette Brev er sikkert skrevet med blødende Hjerte. Komiteen havde i de sidste Aar faaet mange Meddelelser om den stærke tyske Agitation. Allerede omkring I 86o begyndte Klagerne at strømme ind over, at Udlaanene gik tilbage. Resolut havde Komiteen fornyet de mest læste Bøger, men forgæves. Grunden til Tilbagegangen i Udlaanene var efter Præsternes Mening Regeringens vaklende Holdning, de savnede den faste Haand. I Komiteens Skrivelse hedder det: „Naar undtages et enkelt Sogn i de blandede Distrikter, nemlig Sørup i Angel, hvor den tyske Agitation efter Udfærdigelsen af Confirmationspatentet atter har begyndt sit Uvæsen, lyde Efterretningerne om Frugterne af vor Virksomhed forøvrigt tilfredsstillende. “ Det var desværre, og det vidste Komiteen godt, ikke alene i Sørup at det var galt. Overalt møder det en, selv den selvsikre Pastor Mule i Fjolde maa indrømme, at det gaar tilbage med Udlaanene, da den slesvigholstenske Agitation tager til Aar efter Aar, og at Laanernes Antal synker lidt efter lidt. Der var desværre ikke mange at tabe af. Pastor Mule har i Bibliotekets bedste Tid haft $4^{8}$ Laanere blandt de Voksne i Sognet, et Sogn paa henved I8oo Indbyggere. I et andet Sogn TumbyStrukstrup er Udlaanet i 1862 nede paa et til to Børn. Vi havde saaledes allerede inden 1864 lidt et kulturelt Nederlag paa de mest udsatte Strøg, tiltrods for de kønne Ord og den stille Forventning at alt kunde vende sig til det gode. Læses de Beretninger, der findes i C. F. Allen: „Det danske Sprogs Historie i Slesvig“, Bd. 2 Side $637-655$, der udkom 1858, saa aander de næsten Sejrens Glæde. Der gaar gennem disse Indberetninger en Tone, der giver Haab om en ny og lykkelig Tid, men hvor ganske anderledes lyder de ikke efter I86o. De Mænd, der 1 $_{\text {185 }}$ I var rejst ned til dette Land med en levende Tro paa, at et Arbejde i Angel og Mellemslesvig for det danske Sprog vilde bære rige Frugter, faar nu andet at føle. Pastor Hagerup i St. Solt kan endog skrive, at naar der en Gang skulde udgives et Modstykke til Mallings Bog, saa skulde den hedde „frække og lumpne Handlinger udførte af Angelboerne“. Pastor Christiansen i Medelby mener, at Befolkningen nok vilde give en god Sum for igen at slippe af med det Danske. Med dyb Vemod var det altid at Pastor H. F. Fejlberg ser tilbage paa de Aar, han levede i Mellemslesvig. Han kan skrive om et knust Arbejde, om 
en Ungdomsdrøm der brast. Er end Varmen for den danske Sag den samme hos ham, som den altid har været, saa forstod han at bøje sig for Realiteter, og dog var og blev det en Gaade for ham, det føles vel nok stærkest i de Ord: „Og nu Forstaaelsen! Ak nej, Folket kunde ikke læse Dansk, ikke forstaa Dansk. Men hvorledes forklares da den underlige Ting at de danske Folkebiblioteker blev saa stærkt brugte? Børnene kom jo og hentede Bøger. „Hvem læser i dem?" Ja, man fik mange forskellige Svar, sommetider at Forældrene læste, sommetider at Børnene læste højt for Fader og Moder. Og hvorfor havde Civilregeringen saa travlt med at faa alle Bogsamlinger konfiskerede?" Svaret er og bliver ogsaa paa dette: den alt nedbrydende slesvigholstenske Agitation.

Endnu staar tilbage at skildre Bibliotekernes Skæbne. Da Freden var sluttet den 31. Oktober I864, forsøger Komiteen at faa Samling paa det, der var. Den kunde godt have nynnet, hvis Tiden havde været til det: „Det har stormet og pisket i vor Lund“. Det kan roligt siges, at der havde faret et voldsomt Uvejr hen over Landet, naar der er Tale om Bibliotekerne; der var kun Stumper tilbage af fordums Herlighed. Selv om de sidste Aar forud for Krigen havde været nedtrykkende i Angel og Mellemslesvig, saa havde Komiteen vel næppe ventet, at det skulde komme til at se saadan ud over hele Sønderjylland, som det gjorde. I et ligelydende Brev, der er dateret den 28. Sept. I865 og er tilstillet Grev JuelVind-Friis og Brygger Jacobsen, skriver den: „- - Vi savner endnu tilstrækkelig Oplysning om vedkommende Bibliotekers og Læseforeningers Skæbne, men har dog Grund til at antage, at adskillige af dem enten er ødelagte af troløse Fjender eller adsplittede eller maaskee solgte af de nuværende tyske Embedsmænd, i hvilken Henseende det nemlig er kommet til vor Kundskab, at en tysk Præst i et Sogn i Mellemslesvig (Hyrup) end ikke har undset sig ved at stille den Sognet tilhørende værdifulde Bogsamling til Salg i en jydsk Købstad (Fredericia), hvilken Raadighed over fremmed Ejendom vi naturligvis have søgt at forhindre." Det var netop det, der skete. Bibliotekerne stod enten i Skolerne eller i Præstegaardene, og blev de ikke solgte, adsplittede eller ødelagte, saa blev de ganske roligt stillede op paa Lofterne og dermed satte ud af Virksomhed. De spredte Forsøg, der blev gjorte af Komiteen for at hindre dette, havde ingen som helst Betydning, hverken nord eller syd for den nuværende Grænse. Det blev saa forsøgt at skabe ny Forbindelser, men de fik ingen samlende Betydning. Der var $i$ de første Aar efter Krigen en stærk og god Forbindelse mellem Komiteen og Flensborg, og her var det i særlig Grad Overlærer Monrad, der var den ledende. I 1866 havde Komiteen Forbindelse med 2 I gamle Bogsamlinger, men alt eftersom Lærerne gik af eller rejste nordpaa, ebbede Forbindelserne ud; 
i 1876 havde den kun Forbindelse med to, og i dette Aar standsede den sin Virksomhed.

Et Par af de Mænds Navne, som Komiteen havde haft Forbindelse med i Tiden fra r 864 til i 876, bør nævnes. Overlærer Monrad stod Komiteen nærmest, da alle Embedsmænd var flygtede, og ved hans Side stod Hans Mikkelsen Tofte, ude i Periferien skimtes Gustav Johannsen. Blandt de andre skal kun nævnes Skrumsager i Københoved og P. Skau i Bukshave. Det eneste, Komiteen kunde udrette, var at være Mellemled, selv havde den ingen Penge og kunde heller ingen opdrive. De faa Midler, der var i Behold og som den med megen Møje fik, havde ingen Betydning. Til dette kom, at Komiteens Medlemmer døde. I I 876 stod den 77-aarige Justitsraad Mangor ene tilbage. Det var dog lykkedes $i^{*}$ dette Tidsrum at sende alt hvad Komiteen havde ned til Sønderjylland, alt $i$ alt I0,273 Bind og Smaaskrifter, det meste var Smaaskrifter. Den gamle Mand havde ingen Kraft til at tage Sagen op, men endnu inden Døden naaede ham, var den ny Tid kommen.

Ved at sysle med Folkebibliotekernes Arbejde i Tiden mellem Krigene er der et Spørgsmaal, der uafbrudt vender tilbage og kræver et Svar. Alle de, der stod i Spidsen for Arbejdet og udførte Arbejdet, var Embedsmænd, sydfor Grænsen var de det alle, det laa i Tiden, men hvad om det nu havde været Folkets kaarne Mænd, der havde baaret Sagen frem, kunde det saa tænkes, at der var kommen den samme Flugt og Fart over Biblioteksarbejdet som i Tiden før Treaarskrigen? Ingen ved det. Det er imidlertid vist, at det var en Fejl, at Folket ikke blev draget med ind i Arbejdet, mens Tid var, og det især da Forholdene udviklede sig saaledes som de gjorde. Der har været, det skal ikke nægtes, en dyb Mistro til den menige Mand, som Folket blev kaldt paa den Tid, fra saavel Komiteens som fra de Embedsmænds Side, der kom til at virke hernede. Anderledes kan og bør det ikke forstaas, naar Komiteen henvender sig til Amtsforvalter Worsaae i Aabenraa i Stedet for til Fr. Fischer. Worsaae, alle hans gode Sider ufortalte, har ikke haft nogen Forbindelse med Folket, hvilket derimod i høj Grad var Tilfældet med Fr. Fischer. Fischer havde ikke blot Forbindelsen i Orden, men han havde, hvad mere var, en Indsigt og Forstaaelse af Forholdene, som de nye Embedsmænd ikke kunde have. Det samme gentager sig overfor de fire Mænd, der har skreven under paa Aabenraa-Opraabet, de kendes ikke af Komiteen, da der skal oprettes selvstændige Biblioteker i de Sogne, hvor de bor. Af den Grund maatte det hele synke i Grus, da Tiden blev en anden. Det havde været en absolut Styrkelse for hele Arbejdet, hvis Embedsmændene havde forstaaet at drage Befolkningen med ind i Arbejdet, i Stedet for at holde den udenfor. 
Denne Mistillid fortsattes efter Krigen, den gamle Tids Mænd — det var og blev hele den nationalliberale Embedsstand, der virkede hernede - kunde eller vilde ikke forstaa, at Tiden efter I 864 krævede nye Tilstande. Derfor blev ogsaa alle Drøftelser, hvad enten de holdtes paa Møder eller blev skrevne i Breve, betydningsløse. Dette hører imidlertid ikke med her, men nævnes kun for at forstaa Vanskelighederne der var at overvinde, for atter at rejse det ny Arbejde med Bibliotekerne. Et Held er det derfor, at den gamle Tids Idé om Embedsmanden som den førende stedtes til Graven omtrent samtidig med, at "Comiteen til Oprettelsen af danske Folkebiblioteker i Slesvig" holdt op med at virke.

Der var, selv om de ovennævnte Forhold maa beklages, trods alt udført et stort Arbejde i den Tid, her er omhandlet. Der var gjort et Forsøg paa „at drage Befolkningen umærkeligt hjemad til sit rette Dannelseshjem “. Det glippede i de blandede Distrikter, men efterlod dog stærke Spor. Nordfor Grænsen i de rent danske Egne har det været af enorm Betydning; der var naaet det store, at Kendskab til den danske Bog, til dansk Litteratur, banede Vej for dansk Læsning, og dette Forhold kan ikke vurderes stærkt nok, naar Talen er om det danske Sprogs Bevarelse i det nuværende Grænseomraade. Var Organisationsformen end svag i hele det Arbejde, der var bleven udført, saa har den dog lettet den kommende Tids Mænd Arbejdet, da nye Organisationer skulde skabes. I det store og hele, med visse Forbehold, saa maa det siges, at der blev gjort, hvad gøres kunde for at frelse det danske Sprog fra Tilintetgørelse paa de Strøg, hvor det endnu levede. Det er muligt, at de har Ret, der istemmer Fordømmelsen over det, der skete fra Myndighedernes Side, men paa et Punkt maa denne Dom forstumme, og det er overfor det Arbejde, der blev udfort for Oprettelsen af danske Folkebiblioteker.

Bag dette Arbejde, med alle dets Mangler, laa Idealismen ren og klar. Arbejdet stillede sig ikke i Politikens Tjeneste, selv om det havde en politisk Hensigt. Det sørgelige er, at vi led et Nederlag i Kampen for det danske Sprogs Bevarelse i Angel og Mellemslesvig. Dette Kulturnederlag er skæbnesvangert, da det ikke vil kunne genoprettes, hvad vi her har tabt. I864 er ikke glemt, og endnu mindre Tiden, der fulgte, hvor Kulturkampen blev endnu haardere og farligere for det danske Sprog. Et vigtigt Led i denne Kamp blev paany den danske Bog, men denne Gang baaret frem af Folket selv; det skete i i 88o ved Oprettelsen af „Foreningen til det danske Sprogs Bevarelse i Nordslesvig“. 